couldn't keep from wondering, too, whether he ever found it.

Ten specific areas in which students in economics and business will be working such as economic theory, statistics, money, and banking, etc., are listed in Section IV. For each of the areas, information concerning the housing of special materials relating to it is given and important bibliographies are provided.

On the whole, this manual should fulfil its purpose admirably. Dr. Cole, while skirting the pitfall of too much detail in his delineation of an extremely complex situation, has included the essential. He has not assumed too much knowledge on the part of the guide's intended users, has avoided the terminology of library science, and yet the manual is far from elementary. An impor- tant value the student will derive, aside from the primary one of the minimization of trial and error, is the conception he will gain of the wealth of library materials available to him and the painstaking care he must use to uncover them.

In his preface Keyes D. Metcalf states that if the manual accomplishes its purposes, similar ones will be prepared for graduate students in other broad subject fields. It occurs to one that much of the material in the present manual is basic to research in any field and will have to be repeated in subsequent ones. For example, of the ninety-four titles cited, more than half cover all fields of knowledge. However, this may prove to be no disadvantage. And Harvard has set an example that other large university libraries may well consider following.-Ruth $W$ alling.

\title{
Faculty Personnel
}

Problems of Faculty Personnel. John Dale Russell, editor. (Proceedings of the Institute for Administrative Offices of Higher Institutions, 1946, v. 18.) Chicago, University of Chicago Press, 1946.

The eighteenth volume in the Proceedings of the Institute for Administrative Offices of Higher Institutions constitutes a course in the proper treatment of professors, from contract to retirement. The course has thirteen lessons, composed of the papers of the institute, and was planned by a veteran instituter, John Dale Russell, who is now director of the Division of Higher Education in the U.S. Office of Education.

The papers deal in logical sequence with the major aspects of faculty management, beginning with a well-marshaled discussion of determining needs for instructional staff members by Vice President Brumbaugh, of the American Council on Education, and ending with a reasoned treatment of the difficult problem of evaluating faculty services by Ralph Tyler, of the University of Chicago. Between are papers on the preparation, selection, appointment, induction, inservice training, and housing of faculty personnel.

All the authors are professors and administrators of education. They look at faculty personnel problems from the "inside," as members and directors of faculties. From this viewpoint accrues the strength and weakness of the volume as a whole. It is filled with practical wisdom based on experience. The wise comments and the examples of forward-looking personnel practices suggest many promising adaptations to the reader. But it treats faculties in splendid isolation from personnel in other walks of life and profits in no way from advances in knowledge of human relations and group direction which is being carried forward by the very faculties discussed.

Like most proceedings, the present collection remains a group of more-or-less related papers and lacks a unifying body of principle. The student and practitioner will tend quite properly to pick one or another article related to an immediate problem or interest and not many will be tempted to read the collection as a whole. The volume presents a series of contributions to the practice of personnel management in education but it is not a notable addition to the theory of personnel administration.

Several of the authors were evidently selected because they possessed personal knowledge of specific programs of effective faculty management and were encouraged to describe these programs. Thus, Frank Lankard recounts the cooperative plan for select- 
ing new staff members at Brothers College of Drew University, B. Lamar Johnson describes the special program for inducting faculty members at Stephens College, Malcolm Willey arouses envy in at least one metropolitan faculty apartment-dweller with his account of the faculty housing program at the University of Minnesota, and Reuben Frodin makes a good case for the controversial "full-time appointments" at the University of Chicago. Because such examples and speakers were chosen with discrimination, the several papers of this type rise above the level of personal testimony on "how we do it at our institution."

Four papers are devoted to the academic preparation of faculty members, one for the junior college by James Reynolds, of the University of Georgia, one for liberal arts colleges by W. W. Whitehouse, of Albion College, one for graduate teachers by Fer- nandus Payne, of Indiana University, and one for, teachers in technical schools by L. L. Jarvie, of the New York State Education Department. These contributions are the weakest in the volume. The scope and familiarity of these topics invites commonplace comments, which in this case are unrelieved by new insights into means for producing the "raw material" which will be selected, inducted, housed, and retired.

Staff members of academic libraries constitute one portion of the faculty personnel which this volume discusses. Administering librarians in colleges and universities are among the faculty managers to whom the volume is addressed. The staff member can read it asking, "How does it apply to me?" and the administering librarian can read it asking, "What does it suggest for my personal policies?" Both will find frequent and provocative answers.-Lowell Martin.

\section{New Reference Tools}

U.S. Library of Congress. Catalog Maintenance Division. Cumulative Catalog of Library of Congress Printed Cards, January 1947. Washington, Library of Congress [1947.] 71p.

Special Libraries Association. Michigan Chapter. Union List of Serials in the Libraries of Metropolitan Detroit, Compiled as a Joint Project of the Michigan Chapter of the Special Libraries Association and the Detroit Public Library, under the Direction of a Special Committee. Mabel Louise Conat, Chairman. . . . Detroit, Wayne University Press, 1946. 670p.

Judged on the basis of the first monthly issue, this is an important reference as well as cataloging tool. It is to appear monthly with quarterly and annual cumulations. The monthly and quarterly numbers will list only publications issued since January 1939, but the annual volume will include all cards printed during the year regardless of imprint date. The inclusion of essential added and cross references and of many foreign titles greatly enhances its reference and biblio- graphical value, while the very large proportion of cards from research libraries other than the Library of Congress makes it particularly helpful to librarians working with interlibrary loan. In format the Cumulative Catalog is slightly larger than the Catalog of Printed Cards which it supplements and, although it has more entries per page, it seems reasonably legible.

The list of the Michigan Chapter of the Special Libraries Association is a record of the serial holdings of thirty-nine libraries in Detroit as of January 1943 with the addition, in a few instances, of certain important titles acquired since then. It will, of course, be of most interest and value to the cooperating libraries and to others near Detroit. However, the fact that it includes many titles outside the scope of the Union List of Serials in Libraries of the United States and Canada and others of more specialized and local interest not found there makes it very useful as a new source of bibliographical information as well as a means of locating titles.-Jean F. Macalister. 